\title{
Beyond the Bile Duct: Advanced IR Endoscopic Interventions Involving the Gastrointestinal, Genitourinary and Musculoskeletal Systems
}

\author{
Travis L. Healey, $M D^{1}$, Arielle VanSyckel, $M D^{1}$, Joshua Scantland, $M D^{2}$, Nabih \\ Diab, $\mathrm{MD}^{2}$, Matthew S Johnson, MD ${ }^{1}$ \\ ${ }^{1}$ Department of Radiology and Imaging Sciences, Indiana University School of \\ Medicine \\ ${ }^{2}$ St. Vincent Hospital, Department of Internal Medicine
}

All authors have read and contributed to this manuscript.

The authors have the following disclosures: Research support from BTG. Consulting fees from Argon, Boston Scientific, Bristol Myers Squibb, BTG, Cook, Eisai.

\section{Correspondence/Reprints:}

Travis L. Healey, MD Indiana University School of Medicine Dept. of Radiology and Imaging Sciences 550 N. University Blvd. Room 0063 Indianapolis, IN 46202 Phone: 618-972-9117

Alt Phone: 317-944-1866

This is the author's manuscript of the article published in final edited form as: 


\begin{abstract}
Endoscopy is a technique used by interventional radiology (IR) in only a few centers throughout the United States. When used by IR, endoscopy is most well-known for its role in the treatment of hepatobiliary disease. However, its use with relation to pathology involving the gastrointestinal (GI), genitourinary (GU) and musculoskeletal (MSK) systems is gaining momentum among IR. The purpose of this article is to demonstrate the potential benefits of IR endoscopy in non-biliary intervention. A literature review, not requiring IRB approval, was performed via PubMed and Ovid Medline databases using the search terms "interventional radiology-operated endoscopy", "interventional endoscopy", "interventional radiology", "genitourinary", and "gastrointestinal". Literature describing IR endoscopy involving the GI, GU, and MSK systems were identified and described. Nine peer-reviewed articles were identified. While few studies were identified, a general theme suggesting a synergistic relationship between IR and endoscopy was noted. More studies are needed to better understand the role of endoscopy as a technique in the IR suite.
\end{abstract}

KEY WORDS: Endoscopy; Interventional Radiology; gastrointestinal; genitourinary; musculoskeletal

ABBREVIATIONS: IR - Interventional Radiology, IRE - Interventional radiologyoperated endoscopy, GU - genitourinary, GI - gastrointestinal, MSK musculoskeletal 


\section{INTRODUCTION}

Since its inception in 1805, endoscopy has enhanced diagnostic and interventional capabilities via direct visualization of internal body structures [1, 2]. Technological advances such as fiberoptic technology have increased its effectiveness [1].

In the context of IR, endoscopy was first established as an adjunct modality in image-guided procedures within the biliary system, primarily in the setting of calculus disease [3-5]. In 1976, Yamakawa et al. documented one of the earliest accounts of the successful utilization of IR endoscopy in the treatment of choledocholithiasis [6]. In 1986, the American Roentgen Ray Society published an article proposing a question entitled, "Should Radiologísts Perform Endoscopy?" Reference was made to the common use of endoscopy by radiologists in Great Britain and Scandinavia at that time and to the transition of endoscopy to surgery from gastroenterology alone. Persistently relevant is its attention to the increased clinical responsibility that accompanies endoscopy, which in turn would be supported by the increased emphasis placed on developing clinical acumen in IR residencies $[7,8]$

Given the successful use of IR endoscopy in the treatment of select hepatobiliary diseases, there has been a natural progression to extend these techniques to other body systems. Specifically, there has been an increased interest in the utilization of IR endoscopy in performing genitourinary (GU), gastrointestinal (Gl), and musculoskeletal interventions [9-17]. The benefits of direct visualization provided by endoscopy have been demonstrated to facilitate intervention in complex and challenging cases while decreasing radiation to both patients and operators $[4,5]$. The purpose of this review is to demonstrate the potential benefits of IR endoscopy in non-biliary intervention.

\section{METHODS}

PubMed and Ovid Medline were searched using combinations of the terms, "interventional radiology-operated endoscopy", "interventional endoscopy", "interventional radiology", "genitourinary", and "gastrointestinal". Related articles were also reviewed. In addition, reference sections of published relevant articles were searched for additional articles. Article results were categorized as "Gastrointestinal", "Genitourinary", or "Musculoskeletal". For the purpose of this 
review, only endoscopic procedures performed by radiologists are included in the results, although it must be noted that a report of another medical specialty using combined interventional radiology and endoscopy techniques in creative application can be found in the literature and is included in the discussion.

\section{RESULTS:}

In this review, nine peer-reviewed articles were identified and chosen for discussion. These articles were selected on the basis that they described either a case report or case series in which IR directed endoscopic procedures were performed.

\section{Gastrointestinal}

Three articles reported the combined use of interventional radiologyoperated fluoroscopy and endoscopy in the placement of gastrointestinal stents. "Gastrointestinal Stenting" from Zollikofer et al. reported a technical success rate of $95 \%$ and a clinical success rate of $93 \%$ for gastroduodenal stenting in the setting of gastroduodenal outlet obstruction, and their personal institutional practice favored combined fluoroscopy and endoscopy over either modality alone [18]. That methodology was reinforced in an article published in 2000 by Mauro et al [19]. De Gregorio et al. reported the helpful role of IR endoscopy for proximal colonic obstructions and in cases of significant colonic angulation [20]. Furthermore, the authors reported that in their own nonrandomized study, the results showed decreased mean radiation dose and decreased mean procedural time when using the combined fluoroscopic and endoscopic approach despite longer mean distance to the obstructing lesion, although statistical significance was not reported [20].

In a 2018 article from Khayat et al, the role of gastrostomy access for endoscopy in patient populations where esophagogastroduodenoscopy is limited or demanding (such as those with impairments post cerebrovascular accident due to high aspiration risk or those with obstructing upper gastrointestinal lesions due to malignancy) was discussed. It reported a series of three cases in which interventional radiologists safely used gastrostomy access to perform endoscopic retrieval of foreign bodies [16]. Another IR gastrointestinal endoscopy case report described the percutaneous re-access of prior gastrojejunostomy tract for endoscopic evaluation and diagnosis of Graham patch dehiscence with periduodenal abscess following Roux-en- $Y$ gastric bypass, with subsequent drain 
placement, obviating major abdominal surgery in that patient [16]. A third report described a novel adjunct endoscopy application in a patient requiring feeding access following pancreaticoduodenectomy with gastrojejunostomy; after failure of both endoscopy alone and fluoroscopy alone due to the complexity of the postsurgical anatomy, with multiple-day delay of enteral nutrition, the percutaneous transgastric jejunostomy placement was performed by an interventional radiologist using both fluoroscopic and endoscopic guidance [11]. Figure 1 is from our case in which, after fluoroscopically-guided replacement was unsuccessful, endoscopy in combination with fluoroscopy allowed location and traversal of the pylorus and subsequent replacement of a a gastrojejunostomy tube which had coiled in the stomach of a patient status post pancreatic transplant.

\section{Genitourinary}

Select genitourinary procedures may benefit from adjunct endoscopy, according to Srinivasa et al 2017 [3]. One such case was described by Chick et al; after failure of fluoroscopic-guidance alone, a single-use disposable ureteroscope was used with direct fluoroscopic guidance via trans-pyelovesicostomy access to stent the anastomotic stenosis of the pyelovesicostomy in a renal transplant patient. They reported technical success of stenting along with clinical resolution of the patient's flank pain and decreased creatinine levels. In this case, ureteroscopy proved invaluable after the stenosis of altered surgical anatomy rendered fluoroscopic visualization of the anatomic target impossible [10]. Figure 2 comprises images of endoscopic placement of ureteronephric (UN) stents in a morbidly obese woman with a leaking, infected ileal conduit status post cystectomy for bladder cancer. Bilateral nephrostomy tube placement was requested. However, using GU endoscopy, we were able to access the ileal conduit, locate and cannulate both ureters, and place bilateral UN stents.

Two articles presented the use of adjunct nephroscopy in cases of migrated renal arterial embolization coils requiring retrieval, a procedure with risk of hemorrhage, especially after coil incorporation into the renal pelvis epithelium. Fluoroscopic retrieval, with aid from nephroscopic technique, multiple successful coil retrievals were safely conducted, with rapid resolution of arterial hemorrhage encountered during one procedure $[9,15]$.

\section{Musculoskeletal}


A case report by Honda, et al, described the use of joint fluoroscopy and arthroscopy by radiologists for the diagnosis and treatment of painful synovial chondromatosis. The authors reported using a thin flexible fiberoptic scope inserted with fluoroscopic guidance into the temporomandibular joint to visualize, evaluate, and subsequently irrigate the joint [21]. The use of fluoroscopy-guided IR endoscopy in the treatment of lumbar disc herniations was reported by Reul et al. as an alternative to microsurgery, with shorter hospital stays and quick recoveries in the patients treated with minimally invasive fluoroscopy-guided endoscopic procedures [22].

\section{DISCUSSION}

GI IR endoscopy began with the colonic stent, an intervention used to palliate or temporize obstruction, increasing quality of life in terminal settings and obviating emergent surgery or the creation of unwanted colostomies. While endoscopy is not always necessary, it has the potential to be invaluable in the treatment of obstruction in non-surgical candidates and/or patients with surgically altered anatomy. As reported above, some clinicians prefer the combined modality in all cases. Of interest, the American Society of Gastrointestinal Endoscopy has endorsed the European guidelines for self-expandable metal stents in the case of obstructing colonic cancer. Those guidelines recommend combined fluoroscopy and endoscopy. IRs familiar with biliary endoscopy may be able to apply those skills to aid the successful completion of difficult GI interventions.

The wide spectrum of potential GI uses of endoscopy is becoming increasingly evident, with innovative management of high-stakes scenarios such as diagnostic and therapeutic interventions in populations with complex postsurgical anatomy or physical impairments that may alter the function or location of bowel (i.e. ascites, intrabdominal/retroperitoneal mass, neurologic conditions, and prior bariatric interventions). Similarly, the uroscopic case reports clearly show that novel uses of adjunct endoscopy will often be found in complex patients that prove difficult to treat for other practitioners and allow value-added care by IR. Facility with adjunct endoscopy allows the interventional radiologist to offer solutions that are unique to our field and of particular advantage to the patients in question. 
While arthroscopy and neuroendoscopy may seem to be niche opportunities, the use of fiberoptic scopes by radiologists in interventional neuroradiological and arthroscopic settings demonstrate the global utility of IR endoscopy as well as the feasibility of acquiring endoscopic skills for the interventional radiologist regardless of subspecialty.

Similarly, there are reports of combined IR and endoscopic techniques in other specialties. An article entitled "The Use of Interventional Radiology Techniques in the Treatment of Pancreatic Fistula" describes a cohort of 46 patients with pancreatic fistulae treated with IR techniques, including balloon pancreatic ductoplasty after endoscopic retrograde cholangiopancreatography with guidewire access, and subsequent fistula embolization with vascular coils and adhesive. They concluded that "the use of interventional radiology methods in the closure of pancreatic fistula is an effective and safe procedure" [24].

In 1986, the American Roentgen Ray Society asked "Should Radiologists Perform Endoscopy?". Thirty-three years later, supported by the evidence of the literature, we believe the answer is clearly yes. These early examples show that radiologic adoption of endoscopy is both feasible and practical, and can help achieve a practice of medicine that "offers the most appropriate tests with as few visits as possible" [7].

\section{CONCLUSION}

Endoscopy has a well-established history as an adjunct to IR techniques, although the full potential of its valuable clinical application is just now becoming recognized. The use of endoscopy within the IR suite in conjunction with fluoroscopy facilitates some procedures and makes many others possible.

\section{REFERENCES}

1. Edmonson, J.M., History of the instruments for gastrointestinal endoscopy. Gastrointest Endosc, 1991. 37(2 Suppl): p. S27-56.

2. Sivak, M.V., Gastrointestinal endoscopy: past and future. Gut, 2006. 55(8): p. 1061-4.

3. Srinivasa, R.N., et al., Interventional Radiology-Operated Endoscopy as an Adjunct to Image-Guided Interventions. Curr Probl Diagn Radiol, 2018. 
4. Venbrux, A.C., et al., Endoscopy as an adjuvant to biliary radiologic intervention. Radiology, 1991. 180(2): p. 355-61.

5. Venbrux, A.C. and C.D. McCormick, Percutaneous endoscopy for biliary radiologic interventions. Tech Vasc Interv Radiol, 2001. 4(3): p. 186-92.

6. Yamakawa, T., et al., An improved choledochofiberscope and non-surgical removal of retained biliary calculi under direct visual control. Gastrointest Endosc, 1976. 22(3): p. 160-4.

7. Shorvon, P. and G. Stevenson, Should radiologists perform endoscopy? AJR Am J Roentgenol, 1986. 147(5): p. 1078-81.

8. Endoscopy Training. British society of gastrointestinal and abdominal radiology. (http://www.bsgar.org/juniors/endoscopy-training-1/). Accessed September 24, 2018.

9. Chick, J.F.B., et al., Prone Transradial Renal Arteriography and Interventional Nephroscopy for the Visualization and Retrieval of Migrated Renal Embolization Coils Causing Flank Pain and Hydronephrosis. J Vasc Interv Radiol, 2017. 28(9): p. 1314-1316.

10. Chick, J.F.B., et al., Disposable Single-Use Ureteroscopy-Guided Nephroureteral Stent Placement in a Patient with Pyelovesicostomy Stricture and Failed Prior Nephroureteral Stent Placement. J Vasc Interv Radiol, 2017. 28(9): p. 1319-1321.

11. Chick, J.F.B., et al., Gastrojejunoscopy facilitates placement of a percutaneous transgastric jejunostomy in a patient with a pancreaticoduodenectomy and multiple-failed feeding tube placements. Radiol Case Rep, 2018. 13(1): p. 142-145.

12. Johnson, E., et al., Interventional radiology-operated endoscopy-assisted retrograde transnasal placement of a retrievable transhepatic covered biliary stent. Radiol Case Rep, 2018. 13(1): p. 153-155.

13. Khayat,M., et al., Percutaneous transgastrostomic interventional radiology-operated endoscopy facilitates foreign body removal using rigid endobronchial forceps. Diagn Interv Radiol, 2018. 24(1): p. 42-45.

14. Phan, J., et al., Erosion of embolization coils into the renal collecting system mimicking stone. West J Emerg Med, 2012. 13(1): p. 127-30.

15. Srinivasa, R.N., et al., Erosion of Embolization Coils into the Renal Collecting System: Removal with Prone Transradial Renal Arteriography and Nephroscopy. J Endourol, 2017. 31(10): p. 1019-1025. 
16. Srinivasa, R.N., et al., Percutaneous transgastric interventional radiologyoperated duodenoscopy for the identification of duodenal perforation and Graham patch dehiscence. Radiol Case Rep, 2017. 12(4): p. 790-793.

17. Srinivasa, R.N., et al., Laser Ablation Facilitates Closure of Chronic Enterocutaneous Fistulae. J Vasc Interv Radiol, 2018. 29(3): p. 335-339.

18. Zollikofer, C.L., et al., Gastrointestinal stenting. Eur Radiol, 2000. 10(2): p. 329-41.

19. Mauro, M.A., R.E. Koehler, and T.H. Baron, Advances in gastrointestinal intervention: the treatment of gastroduodenal and colorectal obstructions with metallic stents. Radiology, 2000. 215(3): p. 659-69.

20. de Gregorio, M.A., et al., Colon stenting: a review. Semin Intervent Radiol, 2004. 21(3): p. 205-16.

21. Honda, K., et al., Interventional radiology of synovial chondromatosis in the temporomandibular joint using a thin arthroscope. Dentomaxillofac Radiol, 2008. 37(4): p. 232-5.

22. Reul, J., Treatment of lumbar disc herniations by interventional fluoroscopy-guided endoscopy. Interv Neuroradiol, 2014. 20(5): p. 538-46.

23. van Hooft, J.E., et al., Self-expandable metal stents for obstructing colonic and extracolonic cancer: European Society of Gastrointestinal Endoscopy (ESGE) Clinical Guideline. Endoscopy, 2014. 46(11): p. 990-1053.

24. Milek, T., et al., The Use of Interventional Radiology Techniques in the Treatment of Pancreatic Fistula. Surg Laparosc Endosc Percutan Tech, 2016. 26(6): p. 473-475. 
Table 1: Advanced IR Endoscopic Interventions Involving the Gastrointestinal System

\begin{tabular}{|c|c|c|c|c|c|c|c|c|}
\hline Author(s) & Year & Country & $\begin{array}{l}\text { Study } \\
\text { Design }\end{array}$ & $\begin{array}{l}\text { Study } \\
\text { Period }\end{array}$ & $\begin{array}{l}\text { Number } \\
\text { of } \\
\text { Patients }\end{array}$ & Objective & Results & Conclusion \\
\hline $\begin{array}{l}\text { Mauro et al. } \\
\text { (16) }\end{array}$ & 2000 & $\begin{array}{l}\text { United } \\
\text { States }\end{array}$ & $\begin{array}{l}\text { Qualitative } \\
\text { research }\end{array}$ & NA & NA & $\begin{array}{l}\text { Describe the development } \\
\text { and newer stent designs } \\
\text { and delivery systems as } \\
\text { they relate to minimally } \\
\text { invasive nonsurgical } \\
\text { therapy for } \\
\text { gastroduodenal and } \\
\text { colorectal obstructions }\end{array}$ & $\begin{array}{l}\text { Benefits: (a) quick and } \\
\text { noninvasive relief of the } \\
\text { intestinal obstruction in } \\
\text { an acutely ill patient; (B) } \\
\text { improve a patient's } \\
\text { overall medical condition, } \\
\text { enabling better tolerance } \\
\text { of definitive surgical } \\
\text { procedure; (c) reduction } \\
\text { of the complexity of the } \\
\text { definitive procedure }\end{array}$ & $\begin{array}{l}\text { Metallic stent } \\
\text { placement within the } \\
\text { alimentary tract has } \\
\text { proven to be beneficial } \\
\text { in patients who require } \\
\text { palliation of their } \\
\text { gastroduodenal or } \\
\text { colorectal obstruction } \\
\text { and should be a part } \\
\text { of the } \\
\text { interventionalist's } \\
\text { armamentarium }\end{array}$ \\
\hline $\begin{array}{l}\text { Khayat et } \\
\text { al. (10) }\end{array}$ & 2018 & $\begin{array}{l}\text { United } \\
\text { States }\end{array}$ & $\begin{array}{l}\text { Case } \\
\text { Series }\end{array}$ & NA & 3 & $\begin{array}{l}\text { Present an alternative } \\
\text { method for foreign body } \\
\text { retrieval through an } \\
\text { existing gastrostomy tract } \\
\text { with the assistance of } \\
\text { endoscopy by } \\
\text { interventional radiology }\end{array}$ & $\begin{array}{l}\text { Technique offers the } \\
\text { benefits of fast procedure } \\
\text { times, reduction in } \\
\text { radiation dose and } \\
\text { fluoroscopy time, and } \\
\text { allows for safer retrieval } \\
\text { of foreign bodies by } \\
\text { using direct visualization }\end{array}$ & $\begin{array}{l}\text { Transgastrostomic } \\
\text { endoscopy and } \\
\text { endobronchial forceps } \\
\text { retrieval facilitates } \\
\text { removal of } \\
\text { gastrointestinal foreign } \\
\text { bodies without } \\
\text { experienced } \\
\text { complications }\end{array}$ \\
\hline $\begin{array}{l}\text { Chick et al. } \\
\text { (8) }\end{array}$ & 2017 & $\begin{array}{l}\text { United } \\
\text { States }\end{array}$ & $\begin{array}{l}\text { Case } \\
\text { Report }\end{array}$ & NA & 1 & $\begin{array}{l}\text { Describe a patient with a } \\
\text { pancreaticoduodenectomy } \\
\text { complicated by a } \\
\text { gastrojejunostomy leak } \\
\text { who underwent } \\
\text { gastrojejunostomy tube } \\
\text { placement utilizing } \\
\text { percutaneous techniques } \\
\text { with fluoroscopy } \\
\text { assistance and } \\
\text { gastrojejunoscopy } \\
\text { guidance. }\end{array}$ & $\begin{array}{l}\text { Successful placement of } \\
\text { gastrojejunostomy tube } \\
\text { in a difficult patient via } \\
\text { percutaneous technique } \\
\text { assisted by fluoroscopy } \\
\text { and endoscopy. }\end{array}$ & $\begin{array}{l}\text { A combined technique } \\
\text { with fluoroscopy and } \\
\text { endoscopy, both } \\
\text { controlled by } \\
\text { interventional } \\
\text { radiology, may be } \\
\text { useful in patients with } \\
\text { complex postsurgical } \\
\text { gastrointestinal } \\
\text { anatomy who require } \\
\text { enteral access }\end{array}$ \\
\hline $\begin{array}{l}\text { De } \\
\text { Gregorio et } \\
\text { al. (17). }\end{array}$ & 2004 & Venezuela & $\begin{array}{l}\text { Qualitative } \\
\text { Research }\end{array}$ & $\begin{array}{l}\text { Nov } \\
1999 \text { to } \\
\text { Dec } \\
2002\end{array}$ & NA & $\begin{array}{l}\text { Describe the main } \\
\text { indications, technique, } \\
\text { complications, and the } \\
\text { clinical and economic } \\
\text { implications of the use of } \\
\text { stents for the treatment of } \\
\text { colonic stenosis an } \\
\text { obstruction }\end{array}$ & $\begin{array}{l}\text { Metallic stent placement } \\
\text { is an adequate } \\
\text { alternative to emergency } \\
\text { surgery }\end{array}$ & $\begin{array}{l}\text { Colonic stenting can } \\
\text { provide an effective, } \\
\text { nonsurgical } \\
\text { decompression of the } \\
\text { obstructed left colon } \\
\text { avoiding an } \\
\text { emergency colostomy }\end{array}$ \\
\hline
\end{tabular}


Table 2: Advanced IR Endoscopic Interventional Involving the Genitourinary System

\begin{tabular}{|c|c|c|c|c|c|c|c|c|}
\hline Author(s) & Year & Country & Study Design & $\begin{array}{l}\text { Study } \\
\text { Period }\end{array}$ & $\begin{array}{l}\text { Number } \\
\text { of } \\
\text { Patients }\end{array}$ & Objective & Results & Conclusion \\
\hline $\begin{array}{l}\text { Srinivasa et } \\
\text { al. (12) }\end{array}$ & 2017 & $\begin{array}{l}\text { United } \\
\text { States }\end{array}$ & $\begin{array}{l}\text { Retrospective } \\
\text { chart review }\end{array}$ & $\begin{array}{l}\text { Jan } \\
2008- \\
\text { May } \\
2017\end{array}$ & 3 & $\begin{array}{l}\text { Describe a novel } \\
\text { approach by } \\
\text { which prone } \\
\text { percutaneous } \\
\text { nephroscopic coil } \\
\text { retrieval is } \\
\text { coupled with } \\
\text { simultaneous } \\
\text { prone transradial } \\
\text { renal arterial } \\
\text { access to } \\
\text { mitigate potential } \\
\text { complication }\end{array}$ & $\begin{array}{l}\text { Migrated embolization } \\
\text { coils were able to be } \\
\text { effectively removed in all } \\
\text { patients }\end{array}$ & $\begin{array}{l}\text { Combining } \\
\text { nephroscopy with } \\
\text { prone transradial } \\
\text { arteriography in } \\
\text { preparation for } \\
\text { procedure- } \\
\text { associated } \\
\text { hemorrhage may } \\
\text { make removal of } \\
\text { migrated coils safer }\end{array}$ \\
\hline $\begin{array}{l}\text { Chick et al } \\
\text { (7) }\end{array}$ & 2017 & $\begin{array}{l}\text { United } \\
\text { States }\end{array}$ & Case Report & NA & 1 & $\begin{array}{l}\text { Describes a } \\
\text { patient with left } \\
\text { pelvic renal } \\
\text { transplant with } \\
\text { distal ureteral } \\
\text { stenosis status } \\
\text { post } \\
\text { pyelovesicostomy } \\
\text { with anastomotic } \\
\text { stenosis of the } \\
\text { pyelovesicostomy }\end{array}$ & $\begin{array}{l}\text { The successful } \\
\text { placement of renal stent, } \\
\text { patient's flank pain } \\
\text { resolved, creatinine } \\
\text { decreased one day after } \\
\text { the procedure. }\end{array}$ & $\begin{array}{l}\text { The combination of } \\
\text { fluoroscopy and } \\
\text { endoscopy opens } \\
\text { doors to many new } \\
\text { procedures and the } \\
\text { potential for } \\
\text { technical success } \\
\text { where there would } \\
\text { otherwise have } \\
\text { been failure }\end{array}$ \\
\hline $\begin{array}{l}\text { Chick et al } \\
\text { (6) }\end{array}$ & 2017 & $\begin{array}{l}\text { United } \\
\text { States }\end{array}$ & Case Report & NA & 1 & $\begin{array}{l}\text { Describes a } \\
\text { patient who } \\
\text { presented with } \\
\text { left blank pain, } \\
\text { chronic } \\
\text { pseudomonal } \\
\text { infections, and } \\
\text { hydronephrosis } \\
\text { from migration of } \\
\text { coils into the } \\
\text { renal collecting } \\
\text { system after } \\
\text { treatment of a } \\
\text { traumatic renal } \\
\text { artery } \\
\text { pseudoaneurysm }\end{array}$ & $\begin{array}{l}\text { Under direct } \\
\text { visualization, coils in the } \\
\text { lower pole infundibulum } \\
\text { and renal pelvis were } \\
\text { removed with rigid } \\
\text { grasping forceps. A } \\
\text { nephrostogram obtained } \\
2 \text { weeks after the } \\
\text { procedure showed no } \\
\text { hydronephrosis, and the } \\
\text { stent was removed. The } \\
\text { patient reported } \\
\text { resolution of flank pain at } \\
5 \text { weeks pole } \\
\text { infundibulum and renal } \\
\text { pelvis were removed } \\
\text { with rigid grasping } \\
\text { forceps }\end{array}$ & $\begin{array}{l}\text { Prone transradial } \\
\text { renal arteriography } \\
\text { and nephroscopy } \\
\text { may be a safe } \\
\text { method for } \\
\text { visualizing and } \\
\text { treating this } \\
\text { complication }\end{array}$ \\
\hline
\end{tabular}


Table 3: Advanced IR Endoscopic Interventions Involving the Musculoskeletal System

\begin{tabular}{|c|c|c|c|c|c|c|c|c|}
\hline Authors(s) & Year & Country & $\begin{array}{l}\text { Study } \\
\text { Design }\end{array}$ & $\begin{array}{l}\text { Study } \\
\text { Period }\end{array}$ & $\begin{array}{l}\text { Number } \\
\text { of } \\
\text { Patients }\end{array}$ & Objective & Results & Conclusion \\
\hline $\begin{array}{l}\text { Honda et } \\
\text { al. (18) }\end{array}$ & 2008 & Japan & $\begin{array}{l}\text { Case } \\
\text { Report }\end{array}$ & NA & 1 & $\begin{array}{l}\text { Provide a description } \\
\text { of the use of } \\
\text { interventional } \\
\text { radiology following } \\
\text { arthroscopy with a } \\
\text { thin arthroscope for } \\
\text { the diagnosis and } \\
\text { treatment of synovial } \\
\text { chondromatosis (SC) } \\
\text { of the } \\
\text { temporomandibular } \\
\text { joint (TMJ). }\end{array}$ & $\begin{array}{l}\text { Thin arthroscopy confirmed } \\
\text { that the SC was at disease } \\
\text { stage II and that synovitis } \\
\text { existed throughout the SC. In } \\
\text { addition, the TMJ pain was } \\
\text { greatly reduced after joint } \\
\text { irrigation }\end{array}$ & $\begin{array}{l}\text { Findings demonstrate that } \\
\text { interventional radiology } \\
\text { with a thin arthroscope is } \\
\text { clinical useful for the } \\
\text { diagnosis and primary } \\
\text { treatment of patients with } \\
\text { painful SC in the TMJ }\end{array}$ \\
\hline $\begin{array}{l}\text { Reul et al. } \\
\text { (19) }\end{array}$ & 2014 & Germany & $\begin{array}{l}\text { Qualitative } \\
\text { Research }\end{array}$ & $\begin{array}{l}2005- \\
2014\end{array}$ & NA & $\begin{array}{l}\text { Provide description } \\
\text { of a } \\
\text { neurointerventional } \\
\text { transforaminal } \\
\text { endoscopic } \\
\text { approach to } \\
\text { sequestered disk } \\
\text { herniation, its } \\
\text { difficulties and } \\
\text { advantages, and to } \\
\text { provide a short } \\
\text { review of the } \\
\text { relevant literature }\end{array}$ & $\begin{array}{l}\text { No statistical results related } \\
\text { to procedural technique. } \\
\text { Focused on } 5 \text { studies. } \\
\text { Compared to microsurgery, } \\
\text { endoscopic operating times } \\
\text { were shorter, and there was } \\
\text { less blood loss and reduced } \\
\text { postoperative pain. Reduced } \\
\text { hospital stay, shorter } \\
\text { postoperative rehabilitation, } \\
\text { return to work was earlier } \\
\text { than after the microsurgical } \\
\text { techniques. Complication rate } \\
\text { was lower in the endoscopic } \\
\text { series. There were no } \\
\text { significant differences in the } \\
\text { clinical outcome }\end{array}$ & $\begin{array}{l}\text { This endoscopic technique } \\
\text { is an important tool in the } \\
\text { management of patients } \\
\text { with disc disease and in } \\
\text { many cases a good and } \\
\text { equivalent alternative to } \\
\text { microsurgery. }\end{array}$ \\
\hline
\end{tabular}




\section{FIGURES}

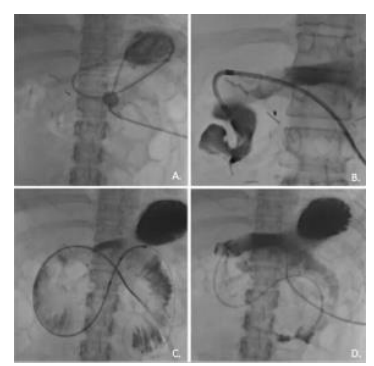

Figure 1. 27-year-old female s/p pancreas transplant with percutaneous gastrojejunostomy (GJ) tube. A. GJ tube coiled in stomach. B. Contrast injected into bowel via percutaneous endoscope to assess anatomy. C. Guidewire and endoscope advanced into jejunum. D. GJ tube advanced over wire to desired position.

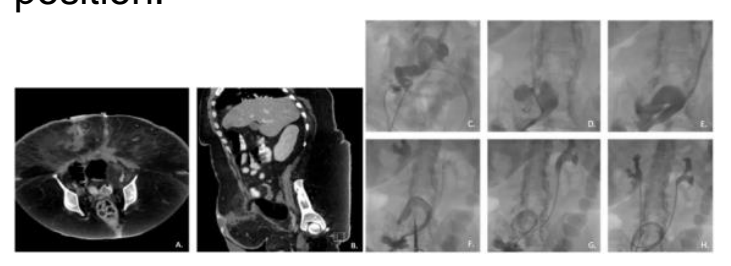

(A)

(B)

Figure 2. 44-year-old female with history of bladder cancer $s / p$ cystectomy and ileal conduit (urostomy) complicated by urine leak and cellulitis. Consulted for bilateral nephrostomy tubes. Endoscopy-assisted placement of bilateral ureteronephric stents instead. A. and B. Axial and sagittal computed tomography. C. Injection of contrast into ileal conduit. D. and E. Identification and reflux of contrast into ureters bilaterally. F. and $\mathbf{G}$. Ureteronephric stent in place (left) and guidewire within collecting system (right). H. Bilateral ureteronephic stents in place. 